ARTICLE

Received 6 Jun 2013 | Accepted 24 Nov 2013 | Published 6 Jan $2014 \quad$ DOl: 10.1038/ncomms4007

\title{
Full open-framework batteries for stationary energy storage
}

Mauro Pasta ${ }^{1}$, Colin D. Wessells ${ }^{1}$, Nian Liu', Johanna Nelson², Matthew T. McDowell', Robert A. Huggins', Michael F. Toney ${ }^{2} \& \mathrm{Yi} \mathrm{Cui}^{1,2}$

New types of energy storage are needed in conjunction with the deployment of renewable energy sources and their integration with the electrical grid. We have recently introduced a family of cathodes involving the reversible insertion of cations into materials with the Prussian Blue open-framework crystal structure. Here we report a newly developed manganese hexacyanomanganate open-framework anode that has the same crystal structure. By combining it with the previously reported copper hexacyanoferrate cathode we demonstrate a safe, fast, inexpensive, long-cycle life aqueous electrolyte battery, which involves the insertion of sodium ions. This high rate, high efficiency cell shows a $96.7 \%$ round trip energy efficiency when cycled at a $5 \mathrm{C}$ rate and an $84.2 \%$ energy efficiency at a $50 \mathrm{C}$ rate. There is no measurable capacity loss after 1,000 deep-discharge cycles. Bulk quantities of the electrode materials can be produced by a room temperature chemical synthesis from earth-abundant precursors.

\footnotetext{
${ }^{1}$ Department of Materials Science and Engineering, Stanford University, Stanford, California 94305, USA. ${ }^{2}$ Stanford Institute for Materials and Energy Sciences, SLAC National Accelerator Laboratory, 2575 Sand Hill Road, Menlo Park, California 94025, USA. Correspondence and requests for materials should be addressed to Y.C. (email: yicui@stanford.edu).
} 
$\mathrm{N}$ ew renewable energy sources such as solar and wind power are fundamentally different from conventional energy generation from fossil fuels because of their inherent intermittency ${ }^{1}$. The power output of solar and wind farms is limited both by diurnal cycles and short-term secondsto-minutes volatility due to rapid changes in cloud cover and wind conditions ${ }^{2}$. The scientific community, industry advocates, and policy makers have repeatedly called for fast-acting energy storage in support of volatile renewable energy sources ${ }^{1-4}$. Energy storage is needed both for diurnal load balancing and the smoothing of intermittent spikes or drops in power production ${ }^{5}$. Energy storage systems used for this application must be deployable across the grid, have extraordinarily long cycle life, be capable of high power charge and discharge in minutes, have very high energy efficiency and, above all, have low capital and lifetime costs.

A new kind of energy storage technology is needed for shortterm grid storage applications, as existing technology struggles to meet the needs of these applications at a reasonable price ${ }^{1,3-5}$. Pumped hydroelectric power is the current industry standard for grid energy storage, but new facilities are location dependent and have very high capital costs. Both mechanical flywheels and ultracapacitors provide the long cycle life, high power, and high energy efficiency needed to smooth volatile renewable energy sources. However, their extraordinarily high costs on a Watt-hour basis have limited their use on the grid thus far. Two battery technologies that are promising for low-rate grid storage applications are sodium sulphur $(\mathrm{NaS})$ and flow batteries. Unfortunately, neither of these types of batteries can operate at high rates, precluding their use for transient applications. Of the existing energy storage technologies, lead acid and lithium-ion batteries are more attractive for transient grid applications, such as short-term smoothing of solar and wind, and both of these technologies have demonstrated some success in grid-scale applications ${ }^{5}$.

Barnhart et al. ${ }^{6,7}$ recently introduced a new metric to evaluate the energetic performance of different storage technologies on the grid. According to their analysis, the two primary factors that are preventing present forms of electrochemical energy storage from being used extensively on the grid are their limited cycle life and high embodied energy (that is, the energy required to build a unit of stored energy). The reason is that previous technologies were never specifically designed to meet the demands of the grid but were instead adapted from other applications in which volumetric/specific energy and power are the key requirements.

We recently demonstrated promising results with a new family of battery electrode materials based on the common, inexpensive Prussian Blue pigment ${ }^{8-11}$. Electrodeposited thin films of these materials have received substantial study in the past for their electrochromic properties, beginning with the pioneering work of $\mathrm{Neff}^{12,13}$. Prussian Blue analogues have also been studied for use as battery electrodes, most commonly as thin films in aqueous electrolytes, but also as cathodes in organic electrolyte lithium-ion cells ${ }^{12,14-24}$.

The open-framework (OF) structure of Prussian Blue analogues is fundamentally different from other insertion electrode materials because of its large channels and interstices. This structure is composed of a face-centred cubic framework of transition metal cations where each cation is octahedrally coordinated to hexacyanometallate groups (Fig. 1) ${ }^{25-27}$. For instance, in the copper hexacyanoferrate cathode, sixfold carboncoordinated iron and sixfold nitrogen-coordinated copper are linked by $\mathrm{CN}$ ligands. Large interstitial 'A sites' within the structure can accommodate zeolitic water and hydrated alkali ions. This results in a general chemical formula of $\mathrm{A}_{\mathrm{x}} \mathrm{PR}(\mathrm{CN})_{6} \cdot \mathrm{nH}_{2} \mathrm{O}$, where $\mathrm{A}$ is an alkali cation such as $\mathrm{K}^{+}$or
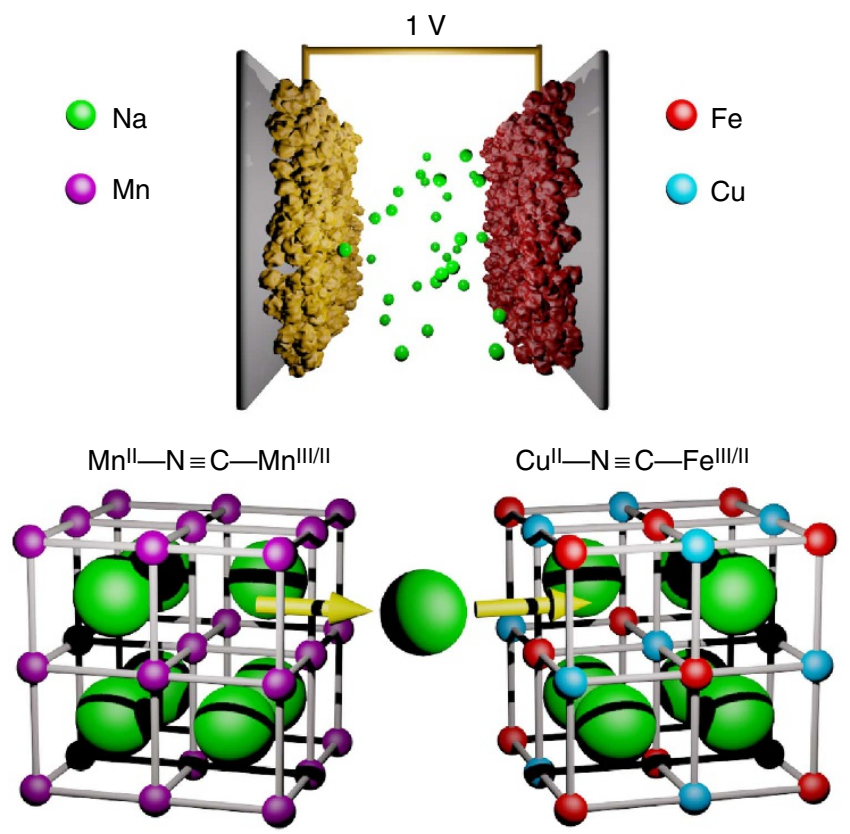

Figure 1 | Symmetric open-framework cell schematic. This new type of safe, fast, inexpensive, long-cycle life aqueous electrolyte battery relies on the insertion of sodium ions into the copper hexacyanoferrate ( $\mathrm{Cu}{ }^{I I}-\mathrm{N} \equiv \mathrm{C}-\mathrm{Fe}^{\mathrm{III} / \mathrm{II}}$ ) cathode and a newly developed manganese hexacyanomanganate $\left(\mathrm{Mn}^{\mathrm{II}}-\mathrm{N} \equiv \mathrm{C}-\mathrm{Mn}^{\mathrm{III} / \mathrm{II}}\right)$ anode, each of which have the same open framework crystal structure.

$\mathrm{Na}^{+}, \mathrm{P}$ is a transition metal cation such as $\mathrm{Cu}^{2+}, \mathrm{Ni}^{2+}$ or $\mathrm{Fe}^{3+}$ and $\mathrm{R}(\mathrm{CN})_{6}$ is a hexacyanometallate anion such as $\mathrm{Fe}(\mathrm{CN})_{6}^{3-}$, $\mathrm{Mn}(\mathrm{CN})_{6}^{3-}$ or $\mathrm{Cr}(\mathrm{CN})_{6}^{3-}$. Both the P-site transition metal cation and the $\mathrm{R}(\mathrm{CN})_{6}^{3-}$ hexacyanometallate anion can be electrochemically active in this structure, hence, in this work, we adopt a notation of the general form $\mathrm{P}^{\mathrm{I} / \mathrm{J}}-\mathrm{N} \equiv \mathrm{C}-\mathrm{R}^{\mathrm{K} / \mathrm{L}}$, where $\mathrm{I}, \mathrm{J}, \mathrm{K}$ and $\mathrm{L}$ are valence states of the $\mathrm{P}$ and $\mathrm{R}$ cations.

The Prussian Blue framework structure has wide channels between the A sites, allowing rapid insertion and removal of $\mathrm{Na}^{+}, \mathrm{K}^{+}$and other ions from aqueous solutions. In addition, there is little lattice strain during cycling because the A sites are larger than the hydrated ions that are inserted and removed from them. The result is an extremely stable electrode: over 40,000 deep discharge cycles were demonstrated in the case of the $\mathrm{Cu}^{\mathrm{II}}-\mathrm{N} \equiv \mathrm{C}-\mathrm{Fe} \mathrm{e}^{\mathrm{II} / \mathrm{II}}$ cathode ${ }^{10}$. We later showed that related cathode materials including nickel hexacyanoferrate $\left(\mathrm{Ni}^{\mathrm{II}}-\right.$ $\left.\mathrm{N} \equiv \mathrm{C}-\mathrm{Fe}^{\mathrm{III} / \mathrm{II}}\right)^{11}$ also have a very long cycle life when operated in a wide variety of aqueous alkali-ion electrolytes ${ }^{8}$, and that their reaction potentials can be controlled by altering their composition ${ }^{9}$.

These OF structure cathodes are ideally paired with an anode that has comparable cycle life and kinetics to avoid a substantial constraint in the performance of the full battery. The activated charcoal used in commercial ultracapacitors has these properties, and we recently showed that it could be successfully combined with the $\mathrm{Cu}^{\mathrm{II}}-\mathrm{N} \equiv \mathrm{C}-\mathrm{Fe}^{\mathrm{III} / \mathrm{II}}$ cathode in an asymmetric cell ${ }^{28}$. However, the low specific and volumetric capacity of capacitive electrodes such as activated charcoal severely limited the specific energy and energy density of this cell. These limitations motivated us to look for anode materials with the same OF crystal structure (and the pertaining attractive properties), but with an insertion potential close to the standard hydrogen electrode (SHE).

In this work, we demonstrate a new symmetric battery that uses OF materials for both its cathode and anode (Fig. 1). In a few 
prior instances, devices of this type have been studied ${ }^{22,23}$. However, in most cases those batteries used impractically small electrodeposited thin film electrodes and used Prussian Blue itself as the anode (resulting in a very low cell voltage of about $0.6 \mathrm{~V}$ ). They also had poor mass-balancing that resulted in the overcharge of one electrode and rapid capacity loss ${ }^{22,23}$. In contrast, in this work we demonstrate the use of manganese hexacyanomanganate $\left(\mathrm{Mn}^{\mathrm{II}}-\mathrm{N} \equiv \mathrm{C}-\mathrm{Mn}^{\mathrm{III} / \mathrm{II}}\right)$ as an anode material that has a low reaction potential, around $0 \mathrm{~V}$ vs SHE, and when combined with cathodes such as $\mathrm{Cu}^{\mathrm{II}}-\mathrm{N} \equiv \mathrm{C}-\mathrm{Fe}^{\mathrm{III} / \mathrm{II}}$, yields a useful full cell voltage of about $1 \mathrm{~V}$. The electrodes in this battery can be synthesized in bulk and when operated in an appropriate aqueous electrolyte show extremely long cycle life, fast kinetics, and high efficiency, resulting in a full battery cell that can be an attractive candidate for use in large scale energy storage.

\section{Results}

Copper hexacyanoferrate cathode. In our previous studies we demonstrated that copper hexacyanoferrate $\mathrm{Cu}^{\mathrm{II}}-\mathrm{N} \equiv \mathrm{C}-\mathrm{Fe}^{\mathrm{III} / \mathrm{II}}$ electrodes are promising for grid-scale energy storage applications because of their ultralong cycle life (83\% capacity retention after 40,000 cycles), high power (67\% discharge capacity available at $80 \mathrm{C}$ ), high energy efficiency and potentially very low $\operatorname{cost}^{7}$.
Copper hexacyanoferrate reacts with $\mathrm{Na}^{+}$by a single-phase insertion reaction:

$$
\begin{aligned}
& \mathrm{Na}_{\mathrm{x}} \mathrm{Cu}_{\mathrm{y}}\left[\mathrm{Fe}^{\mathrm{III}}(\mathrm{CN})_{6}\right]+\mathrm{a}\left(\mathrm{Na}^{+}+\mathrm{e}^{-}\right) \\
& =\mathrm{Na}_{\mathrm{x}+\mathrm{a}} \mathrm{Cu}_{\mathrm{y}}\left[\mathrm{Fe}^{\mathrm{III}}(\mathrm{CN})_{6}\right]_{1-\mathrm{a}}\left[\mathrm{Fe}^{\mathrm{II}}(\mathrm{CN})_{6}\right]_{\mathrm{a}}
\end{aligned}
$$

The standard potential of this reaction is $0.85 \mathrm{~V}$ with respect to the standard hydrogen electrode (SHE), which makes it an ideal material to use as a cathode in aqueous electrolytes. The material used in the experiments described here was synthesized in its oxidized form $\left(\mathrm{Cu}^{\mathrm{II}}-\mathrm{N} \equiv \mathrm{C}-\mathrm{Fe} \mathrm{III}^{\mathrm{III}}\right.$ brown $)$ with the room temperature co-precipitation method previously described and reported in the methods section. X-ray diffraction (XRD), scanning electron microscopy (SEM) and transmission electron microscopy (TEM) results are shown in Fig. $2 \mathrm{~d}-\mathrm{f}$ and discussed below for the sake of comparison with the $\mathrm{Mn}^{\mathrm{II}}-\mathrm{N} \equiv \mathrm{C}-\mathrm{Mn}^{\mathrm{III}}$ anode. The composition of the as-synthesized material was determined by elemental analysis and ion coupled plasma mass spectrometry (ICP-MS) to be $\mathrm{K}_{0.05} \mathrm{Cu}\left[\mathrm{Fe}(\mathrm{CN})_{6}\right]_{0.67} \cdot \square_{0.33}$. $2.83 \mathrm{H}_{2} \mathrm{O}\left(\square=\mathrm{Fe}(\mathrm{CN})_{6}\right.$ vacancy). The as-synthesized CuHCF has a fractional initial charge state because fully oxidized $\mathrm{CuHCF}$ has a potential high enough that it can be reduced by water. A reductive titration method was developed to controllably reduce a
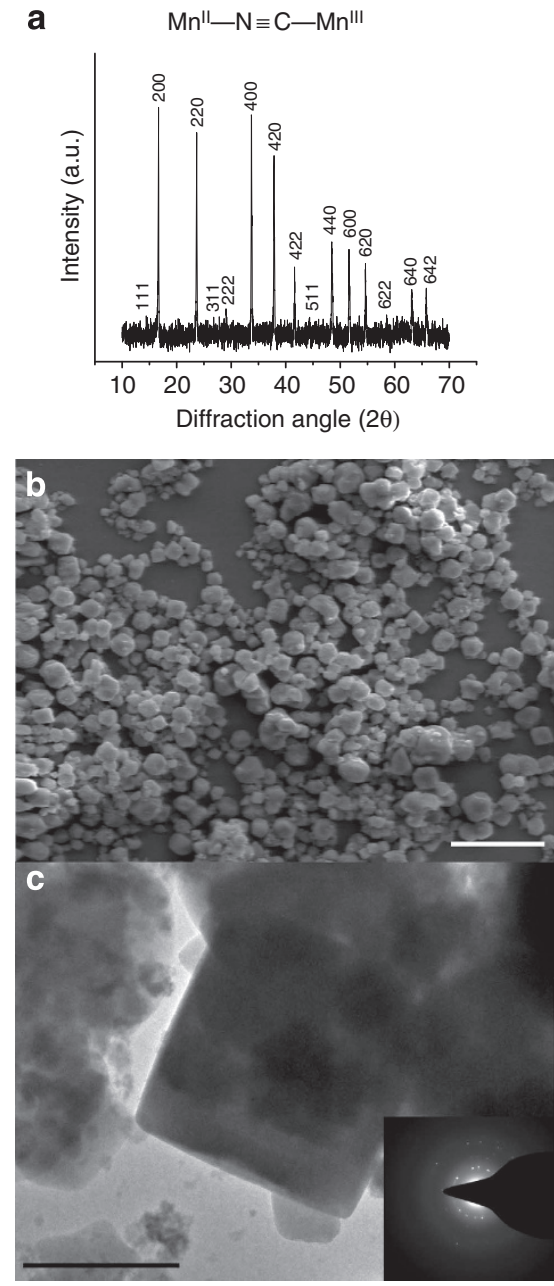

d
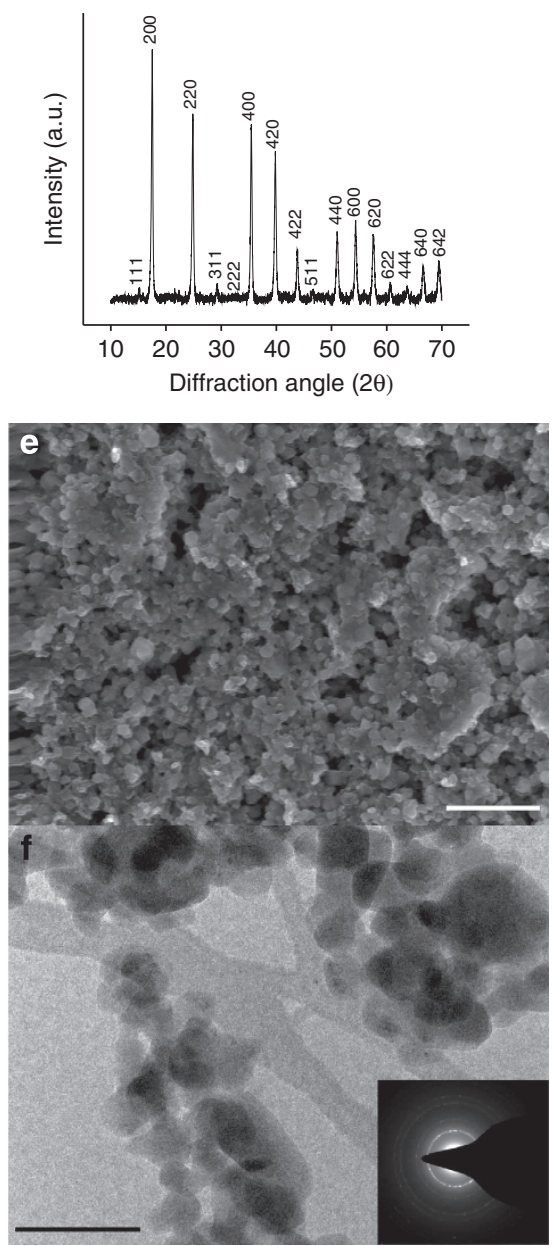

Figure 2 | Manganese hexacyanomanganate and copper hexacyanoferrate physical characterization. $X$-ray diffraction patterns of (a) $M n^{\prime \prime}-\mathrm{N} \equiv \mathrm{C}-\mathrm{Mn}{ }^{\prime \prime \prime}$

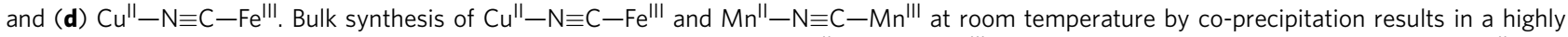
crystalline material. SEM shows particles of the order of $500 \mathrm{~nm}$ for the $\mathrm{Mn}^{\prime \prime}-\mathrm{N} \equiv \mathrm{C}-\mathrm{Mn}^{\text {III }}$ (b, scale bar $=5 \mu \mathrm{m}$ ) and $20-50 \mathrm{~nm}$ for the $\mathrm{Cu}-\mathrm{N} \equiv \mathrm{C}-\mathrm{Fe} \mathrm{e}^{\text {III }}$ $(\mathbf{e}$, scale bar, $1 \mu \mathrm{m})$. These results are consistent with those of TEM of the $\mathrm{Mn}^{\mathrm{II}}-\mathrm{N} \equiv \mathrm{C}-\mathrm{Mn}^{\text {III }}$ (c, scale bar. 500 nm) which show crystalline, faceted nanoparticles and $\mathrm{Cu}^{\mathrm{II}}-\mathrm{N} \equiv \mathrm{C}-\mathrm{Fe} \mathrm{el}^{\mathrm{III}}$ (f, scale bar, $100 \mathrm{~nm}$ ). 
$\mathrm{CuHCF}$ to a desired oxidation state and open circuit potential using $\mathrm{Na}_{2} \mathrm{~S}_{2} \mathrm{O}_{3}$, in the presence of an excess of potassium ions ${ }^{28}$. The fully reduced CuHCF (dark purple) had a composition of $\mathrm{Na}_{0.036} \mathrm{~K}_{0.40} \mathrm{Cu}\left[\mathrm{Fe}(\mathrm{CN})_{6}\right]_{0.60} \cdot \square_{0.4} \cdot 3.17 \quad \mathrm{H}_{2} \mathrm{O}$. The X-ray photoelectron spectroscopy (XPS) spectra of both oxidized and reduced powders are reported in the Supplementary Information (Supplementary Fig. S2).

Electrolyte considerations. Prussian Blue analogues are known to be more stable at acidic $\mathrm{pH}$ than in neutral and basic $\mathrm{pH}$, as ligand exchange between the $\mathrm{CN}^{-}$ligands and $\mathrm{OH}^{-}$ions results in the dissolution and destruction of the Prussian Blue structure ${ }^{29}$. This trace solubility is the dominant loss mechanism during their operation in both battery electrodes and electrochromic devices, thereby acidic $\mathrm{pH}$ has been found to extend the lifetimes of these devices ${ }^{30}$. However, the reductive electrolysis of water to $\mathrm{H}_{2}$ occurs at higher potentials in acid, which in turn limits the use of anodes with low reaction potentials. Moreover, acidic conditions are undesirable for practical reasons, including current collector corrosion, cell packaging and safety. Neutral $10 \mathrm{M} \mathrm{NaClO}_{4}$ was adopted as the electrolyte of choice for this study because the neutral $\mathrm{pH}$ results in a low potential for $\mathrm{H}_{2}$ evolution, and the high salt concentration of this electrolyte also limits the trace solubility of Prussian Blue analogues. The neutral $\mathrm{pH}$ of this solution results in a relatively low equilibrium potential of $0.787 \mathrm{~V}$ for $\mathrm{O}_{2}$ evolution with respect to the standard hydrogen electrode (SHE). Although this is lower than the reaction potential of the $\mathrm{Cu}^{\mathrm{II}}-$ $\mathrm{N} \equiv \mathrm{C}-\mathrm{Fe}$ III/II cathode, in practice, $\mathrm{O}_{2}$ evolution does not occur at an appreciable rate below $1.2 \mathrm{~V}$ vs SHE in this electrolyte thanks to the combination of perchlorate anion adsorption, a decrease in the chemical activity of water, and increased viscosity of the solution. Galvanostatic cycling data and cycle life for the $\mathrm{Cu}^{\mathrm{II}}-$ $\mathrm{N} \equiv \mathrm{C}-\mathrm{Fe} \mathrm{III} / \mathrm{II}^{\mathrm{I}}$ cathode using an activated carbon counter electrode are reported in the Supplementary Information (Supplementary Fig. S4). Finally, the choice of an aqueous, neutral electrolyte results in a safe battery, with no flammability or explosion hazards and limited corrosion.

Open-framework anodes. The development of a suitable anode has proven to be challenging for a wide variety of aqueous electrolyte batteries, for several reasons ${ }^{31}$. Very few of the transition metal oxides and phosphates typically used to intercalate $\mathrm{Li}^{+}$and $\mathrm{Na}^{+}$have reaction potentials between $-0.5 \mathrm{~V}$ and $0 \mathrm{~V}$ vs SHE, the optimal range for anodes in aqueous electrolytes ${ }^{32}$. Some, such as $\mathrm{VO}_{2}$ and $\mathrm{LiV}_{3} \mathrm{O}_{8}$, are partially soluble ${ }^{33}$. If the anode potential is slightly too low, as in the case of the NASICON $\mathrm{A}_{1+\mathrm{x}} \mathrm{Ti}_{2}\left(\mathrm{PO}_{4}\right)_{3}$ $(\mathrm{A}=\mathrm{Li}, \mathrm{Na})$, then the low coulombic efficiency of the anode will result in overcharge of the cathode, unless the cathode potential is tuned to result in commensurate $\mathrm{O}_{2}$ evolution ${ }^{34}$. Other intercalation electrodes such as transition metal sulphides are potentially subject to irreversible hydrolysis. A major advantage of an aqueous electrolyte system is its low cost. This precludes the use of tungsten and molybdenum oxide bronzes and indium oxide that have all been used in aqueous electrolyte electrochromic devices ${ }^{35}$. Development of metal-hydride anodes with high enough reaction potentials for use in neutral $\mathrm{pH}$ may be possible, but the lanthanides they typically contain are generally too expensive. The use of a Prussian Blue analogue as an anode in aqueous alkali ion batteries could overcome these challenges: several materials in this family have reaction potentials in the desired range, and they can be produced rapidly in bulk from inexpensive precursors.

To maximize the voltage and, therefore, the stored energy of an aqueous battery, the reaction potentials of the anode and cathode

\begin{tabular}{|c|c|}
\hline Hexacyanometallate & $\mathrm{E}^{0}$ (V vs SHE) \\
\hline 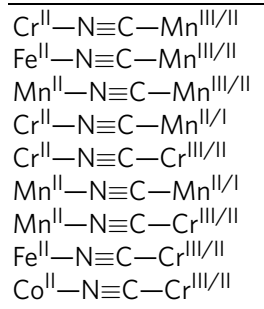 & $\begin{array}{c}0.352 \\
0.075 \\
0.052 \\
-0.312 \\
-0.562 \\
-0.612 \\
-0.804 \\
-0.860 \\
-0.793\end{array}$ \\
\hline
\end{tabular}

must be as close as possible to the potentials for $\mathrm{H}_{2}$ and $\mathrm{O}_{2}$ evolution in the chosen electrolyte. In their early work, Dostal and $S_{c h o l z}{ }^{36}$ investigated many Prussian Blue analogues in aqueous electrolytes. Table 1 summarizes the Prussian Blue analogues that have a potential close to the lower stability limit of pH-neutral aqueous electrolytes.

The energy stored in a battery scales with the voltage, hence lower anode reaction potentials are desirable. However, the equilibrium $\mathrm{H}_{2}$ reduction potential in neutral $\mathrm{pH}$ is $-0.413 \mathrm{~V}$, hence anodes that operate at potentials appreciably lower than this suffer from poor coulombic efficiency and cannot be used. $\mathrm{Cr}{ }^{\mathrm{II}}-\mathrm{N} \equiv \mathrm{C}-\mathrm{Mn}^{\mathrm{III} / \mathrm{II}}$ would result in an impractically low battery voltage of $0.6 \mathrm{~V}$ if paired with the $\mathrm{Cu}^{\mathrm{II}}-\mathrm{N} \equiv \mathrm{C}-\mathrm{Fe}{ }^{\mathrm{III} / \mathrm{II}}$ cathode. $\mathrm{Fe}^{\mathrm{II}}-\mathrm{N} \equiv \mathrm{C}-\mathrm{Mn}^{\mathrm{III} / \mathrm{If}}$ cannot be used in aqueous electrolytes because of rapid $\mathrm{Fe}-\mathrm{N} / \mathrm{Mn}-\mathrm{C}$ isomerization that results in the formation of the $\mathrm{Mn}^{\mathrm{II}}-\mathrm{N} \equiv \mathrm{C}-\mathrm{Fe}^{\mathrm{III} / \mathrm{II}}$ cathode ${ }^{37,38}$.

Of the anodes synthesized in this study, $\mathrm{Cr}^{\mathrm{II}}-\mathrm{N} \equiv \mathrm{C}-\mathrm{Mn}^{\mathrm{II} / \mathrm{I}}$ is the most attractive for use in an aqueous battery at neutral $\mathrm{pH}$, as its lower reaction occurs at $-0.312 \mathrm{~V}$ vs SHE (Fig. 3a). Unfortunately, synthesis of phase-pure $\mathrm{Cr}^{\mathrm{II}}-\mathrm{N} \equiv \mathrm{C}-\mathrm{Mn}^{\mathrm{III}}$ is challenging due to the tendency of the $\mathrm{Cr}^{2+}$ to hydrolyze and $\mathrm{Mn}^{3+}$ to disproportionate. For this reason, the crystallinity of $\mathrm{Cr}^{\mathrm{II}}-\mathrm{N} \equiv \mathrm{C}-\mathrm{Mn}^{\mathrm{III}}$ was too poor to allow a reliable calculation of its lattice parameter, and, although its electrochemical activity was successfully measured (Fig. 3a), its specific capacity was less than half of the $60 \mathrm{mAh} \mathrm{g}^{-1}$ typically observed for Prussian Blue analogues in aqueous electrolytes. Alternatively, manganese hexacyanomanganate was readily synthesized with high crystallinity and purity, resulting in a specific capacity of $57 \mathrm{mAh} \mathrm{g}^{-1}$ for its upper reaction. The lower reaction of this material $\left(\mathrm{Mn}^{\mathrm{II}}\right.$ $\mathrm{N} \equiv \mathrm{C}-\mathrm{Mn}^{\mathrm{II} / \mathrm{I}}$ ) occurs at $-0.612 \mathrm{~V}$ vs $\mathrm{SHE}$, which is too low to allow efficient cycling in $\mathrm{pH}$-neutral electrolytes without appreciable $\mathrm{H}_{2}$ evolution. For these reasons, $\mathrm{Mn}^{\mathrm{II}}-\mathrm{N} \equiv \mathrm{C}-$ $\mathrm{Mn}^{\mathrm{III} / \mathrm{II}}$ was selected as the anode to be used in full cells with the $\mathrm{Cu}^{\mathrm{II}}-\mathrm{N} \equiv \mathrm{C}-\mathrm{Fe}^{\mathrm{III} / \mathrm{II}}$ cathode.

The manganese hexacyanomanganate anode. $\mathrm{Mn}^{\mathrm{II}}-\mathrm{N} \equiv \mathrm{C}-$ $\mathrm{Mn}^{\mathrm{III}}$ was synthesized by precipitation from aqueous precursors at room temperature (see methods section). The as-synthesized material has a composition of $\mathrm{K}_{0.11} \mathrm{Mn}\left[\mathrm{Mn}(\mathrm{CN})_{6}\right]_{0.83} \cdot \square_{0.17}$. $3.64 \mathrm{H}_{2} \mathrm{O} \quad\left(\square=\mathrm{Mn}(\mathrm{CN})_{6}\right.$ vacancy $)$ as determined by $\mathrm{CHN}$ analysis and ICP-MS.

$\mathrm{X}$-ray diffraction of the fresh powders of both $\mathrm{Cu}^{\mathrm{II}}-\mathrm{N} \equiv \mathrm{C}-$ $\mathrm{Fe}^{\mathrm{III}}$ and $\mathrm{Mn}^{\mathrm{II}}-\mathrm{N} \equiv \mathrm{C}-\mathrm{Mn}^{\mathrm{III}}$ revealed that they both have the FCC Prussian Blue crystal structure ${ }^{27}$. Their fully indexed diffraction spectra are shown in Fig. 2a,d. In both cases, the lattice parameter is consistent with those previously reported for these materials ${ }^{39}$.

SEM showed that the morphology of the Prussian Blue analogues reported here varied with composition. The 


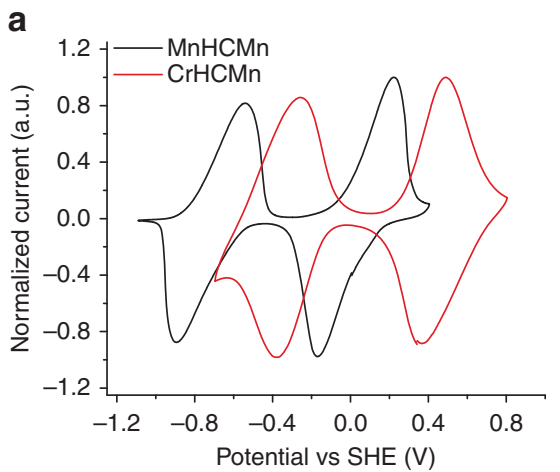

b
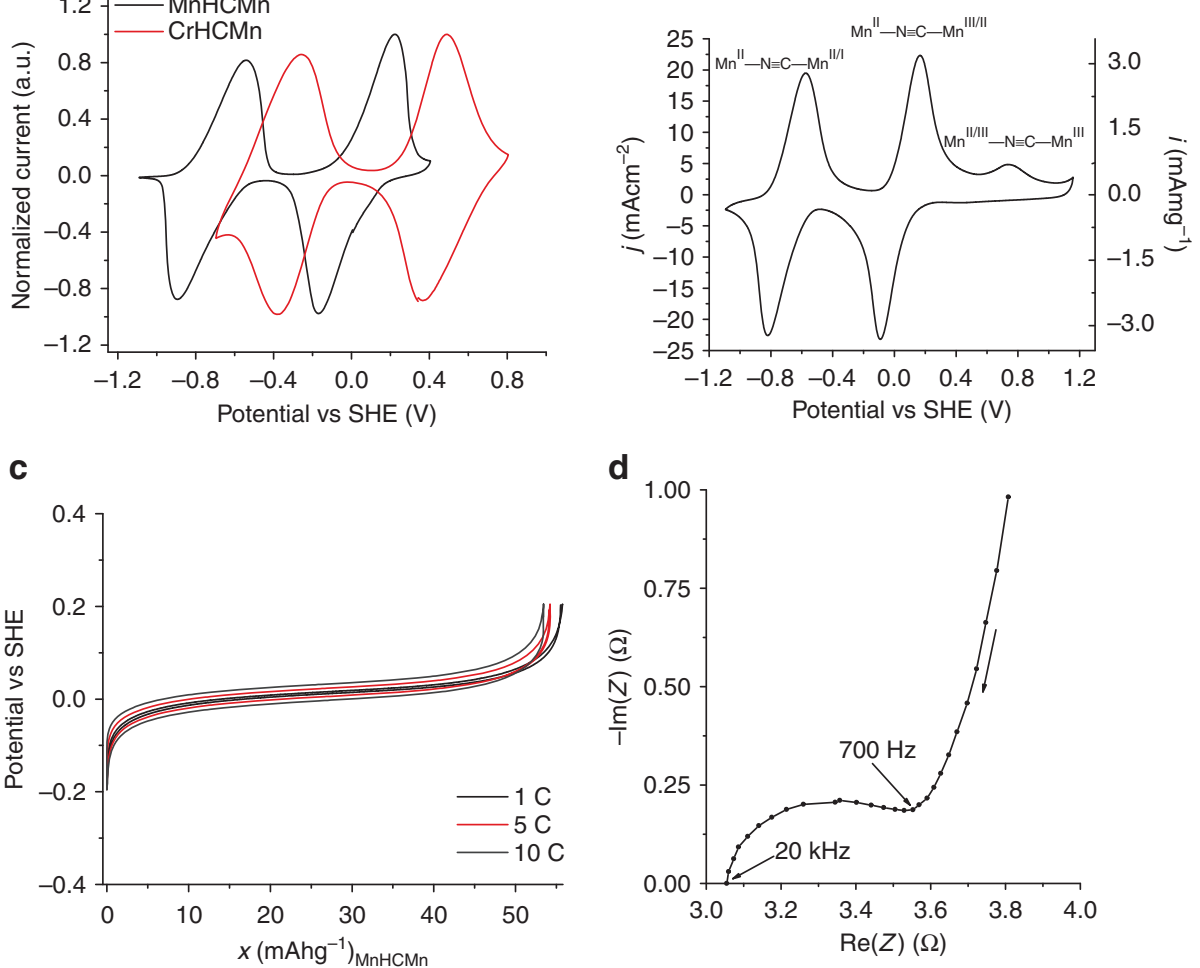

Figure 3 | Manganese hexacyanomanganate electrochemical characterization. (a) The cyclic voltammograms of manganese and chromium hexacyanomanganates in $10 \mathrm{M} \mathrm{NaClO}_{4} \mathrm{pH}=7$ show two electrochemical processes in which the carbon-coordinated manganese reversibly changes its valence state between $+1 /+2$ and $+2 /+3$, respectively. (b) When cycled at higher potentials manganese hexacyanomanganate shows an additional, irreversible electrochemical process attributed to the oxidation of the $\mathrm{N}$-coordinated $\mathrm{Mn}$ from +2 to +3 . Galvanostatic cycling (c) at different $\mathrm{C}$ rates shows very low hysteresis resulting in high energy efficiencies, thanks to the low impedance of the system (d).

$\mathrm{Mn}^{\mathrm{II}}-\mathrm{N} \equiv \mathrm{C}-\mathrm{Mn}^{\mathrm{III} / \mathrm{II}}$ anode is composed of large, faceted particles $0.5-2 \mu \mathrm{m}$ diameter (Fig. $2 \mathrm{~b}, \mathrm{c}$ ), while the $\mathrm{Cu} \mathrm{u}^{\mathrm{II}}-\mathrm{N} \equiv \mathrm{C}-$ $\mathrm{Fe}^{\mathrm{III} / \mathrm{II}}$ cathode is composed of polydisperse nanoparticles about $50 \mathrm{~nm}$ in size (Fig. 2e,f). The anode material precipitated more slowly during synthesis than the cathode material, resulting in the growth of fewer, but larger particles. As will be shown below, the high crystallinity and small particle size of OF materials aid rapid charge transport into each particle, allowing complete charge and discharge of these materials in short times.

The OF materials were processed into electrodes using the standard slurry method widely practiced by the lithium-ion battery research community and manufacturers. These working electrodes were studied in aqueous flooded cells that also contained a $\mathrm{Ag} / \mathrm{AgCl} / 3.5 \mathrm{M} \mathrm{KCl}$ reference electrode and an activated carbon counter electrode.

Figure $3 \mathrm{~b}$ shows the cyclic voltammogram of manganese hexacyanomanganate in $10 \mathrm{M} \mathrm{NaClO}_{4}, \mathrm{pH}=7$ electrolyte. We postulate that both of the reactions observed for the hexacyanomanganate-based anodes are due to the electrochemical activity of the hexacyanomanganate groups and not the P-site nitrogencoordinated manganese. For nearly every electrochemically active OF materials, it is the hexacyanometallate group, and not the nitrogen-coordinated $\mathrm{P}$ site metal cation, that is active. For example, the only electrochemical activity observed for chromiu$\mathrm{m}$ (III) hexacyanoferrate $\left(\mathrm{Cr}^{\mathrm{III}}-\mathrm{N} \equiv \mathrm{C}-\mathrm{Fe}^{\mathrm{III} / \mathrm{II}}\right)$ is that of the hexacyanoferrate group, and, even at very low potentials, the chromium is not reduced ${ }^{37}$. During this study, we found that chromium in chromium(II) hexacyanoferrate $\left(\mathrm{Cr}^{\mathrm{II}}-\mathrm{N} \equiv \mathrm{C}-\right.$ $\left.\mathrm{Fe}^{\mathrm{III} / \mathrm{II}}\right)$ is also electrochemically inactive at low potentials. Among the numerous hexacyanoferrate-based cathodes, the exceptions to this rule are regular Prussian Blue (Fe $\mathrm{Fe}^{\mathrm{II} / \mathrm{II}}$
$\left.\mathrm{N} \equiv \mathrm{C}-\mathrm{Fe}^{\mathrm{III} / \mathrm{II}}\right)$ and hexacyanoferrates of vanadium $\left(\left(\mathrm{V}^{\mathrm{IV}} \mathrm{O}\right)^{2+} /\right.$ $\left.\mathrm{V}^{\mathrm{III}}-\mathrm{N} \equiv \mathrm{C}-\mathrm{Fe}^{\mathrm{III} / \mathrm{II}}\right)^{40}$, titanium $\left(\left(\mathrm{Ti}^{\mathrm{IV}} \mathrm{O}\right)^{2+} / \mathrm{V}^{\mathrm{III}}-\mathrm{N} \equiv \mathrm{C}-\mathrm{Fe}^{\mathrm{III} /}\right.$ II $)^{41}$ and manganese $\left(\mathrm{Mn}^{\mathrm{III} / \mathrm{II}}-\mathrm{N} \equiv \mathrm{C}-\mathrm{Fe}^{\mathrm{III} / \mathrm{II}}\right)^{37}$. The materials containing vanadium and titanium are special cases, as the mechanism of their electrochemical activity is complicated by the formation of oxymetal cations. In the case of $\mathrm{Mn}^{\mathrm{III} / \mathrm{II}}-\mathrm{N} \equiv \mathrm{C}-$ $\mathrm{Fe}^{\mathrm{III} / \mathrm{II}}$, the $\mathrm{P}$-site manganese is electrochemically active only at high potentials near $1.0 \mathrm{~V}$ vs $\mathrm{SHE}^{37}$.

In one recent study, Asakura et al. ${ }^{42}$ found the manganese hexacyanomanganate anode to have two reaction potentials, one near $0.0 \mathrm{~V}$ vs SHE and the other near $0.7 \mathrm{~V}$ vs SHE, when the material was initially synthesized in a fully-reduced, low vacancy state containing only $\mathrm{Mn}^{2}+\left(\mathrm{K}_{1.72} \mathrm{Mn}\left[\mathrm{Mn}(\mathrm{CN})_{6}\right]_{0.93} \cdot \square_{0.07} \cdot 0.65\right.$ $\mathrm{H}_{2} \mathrm{O}$, green). In this study, we also observed both of these two reactions, plus an additional peak at $-0.7 \mathrm{~V}$ vs SHE (Fig. 3b). In our investigation the oxidation/reduction of manganese in the $\mathrm{P}$-site was not reversible due to the high solubility and chemical instability of $\mathrm{Mn}^{\mathrm{III}}\left(\mathrm{Mn}^{\mathrm{III}}-\mathrm{N} \equiv \mathrm{C}-\mathrm{Mn}^{\mathrm{III}}\right)$ in water-based electrolytes. Asakura et al. ${ }^{42}$ observed a reversible phase change from cubic to monoclinic during cycling of the peak that they observed near $0.0 \mathrm{~V}$ vs SHE. However, we found that chemical reduction of the as-synthesized $\mathrm{Mn}^{\mathrm{II}}-\mathrm{N} \equiv \mathrm{C}-\mathrm{Mn}^{\mathrm{III}}$ (light brown) to $\mathrm{Mn}^{\mathrm{II}}-\mathrm{N} \equiv \mathrm{C}-\mathrm{Mn}^{\mathrm{II}}\left(\mathrm{Na}_{0.80} \mathrm{~K}_{0.06} \mathrm{Mn}\left[\mathrm{Mn}(\mathrm{CN})_{6}\right]_{0.83}\right.$. $\square_{0.17} \cdot 2.17 \mathrm{H}_{2} \mathrm{O}$, light blue) using sodium dithionate $\mathrm{Na}_{2} \mathrm{~S}_{2} \mathrm{O}_{6}$ $\left(\mathrm{E}^{0}=-0.66 \mathrm{~V}\right)$ resulted only in a small change in lattice parameter and not in substantial changes to the FCC structure (Fig. 4b).

Physical characterization of MnHCMn at various oxidation states was performed in an effort to understand the mechanism of its electrochemical activity. The bonding in the $\mathrm{Mn}^{\mathrm{II}}-\mathrm{N} \equiv \mathrm{C}-$ $\mathrm{Mn}^{\mathrm{III}}$ structure was examined using Fourier Transform Infrared 

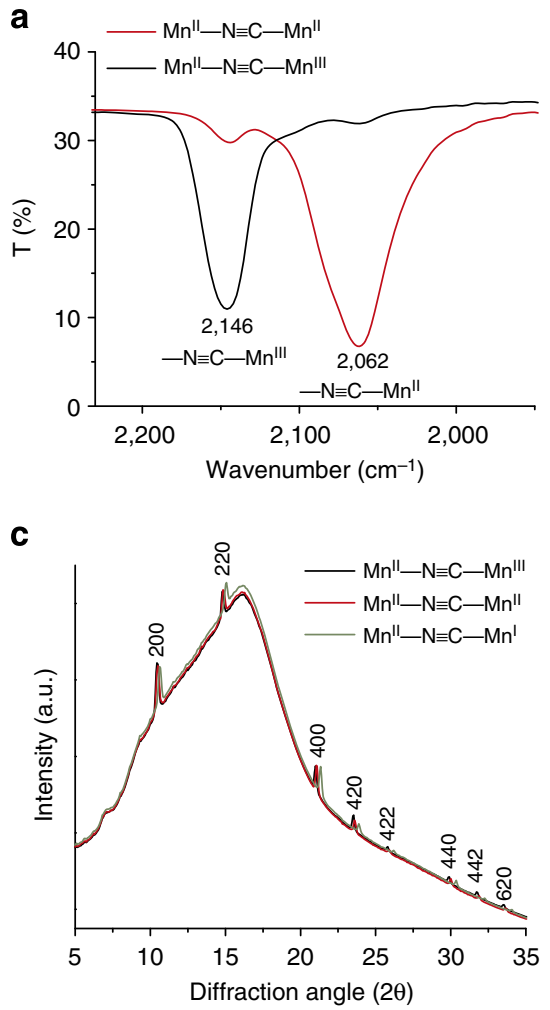

b

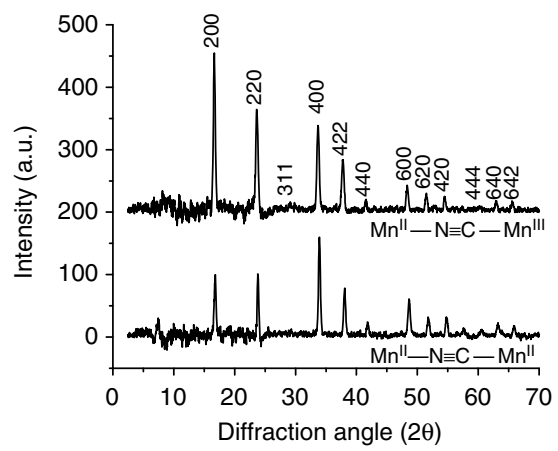

d

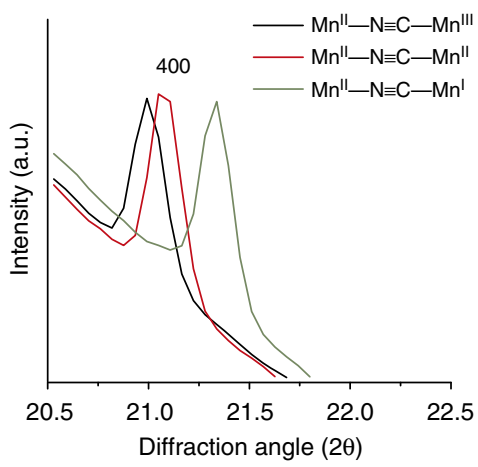

Figure 4 | Manganese hexacyanomanganate physical characterization. (a) Fourier transform infrared spectroscopy of oxidized $\mathrm{Mn}^{\prime \prime}-\mathrm{N} \equiv \mathrm{C}-\mathrm{Mn} \mathrm{n}^{\prime \prime \prime}$ and reduced $\mathrm{Mn}^{\|}-\mathrm{N} \equiv \mathrm{C}-\mathrm{Mn}^{\|}$confirm that the $\mathrm{C}$-coordinated manganese is changing valence state. The in situ synchrotron X-ray diffraction experiment (c,d) shows no change in crystal structure for $M n^{\prime \prime}-N \equiv C-M n^{\prime \prime \prime}, M n^{\prime \prime}-N \equiv C-M n^{\prime \prime}$ and $M n^{\prime \prime}-N \equiv C-M n^{\prime}$ except for a small peak shift corresponding to a decrease in lattice parameter during reduction. The broad background peak is due to the scattering by the water electrolyte (Supplementary Information). These results are confirmed by $\mathrm{X}$-ray Powder Diffraction spectra (b) of oxidized $\mathrm{Mn}^{\prime \prime}-\mathrm{N} \equiv \mathrm{C}-\mathrm{Mn}^{\prime \prime \prime}$ and reduced $\mathrm{Mn}{ }^{\prime \prime}-\mathrm{N} \equiv \mathrm{C}-\mathrm{Mn} n^{\prime \prime}$.

Spectroscopy (FTIR) (Fig. 4a). The infrared stretching frequencies of $\mathrm{M}-\mathrm{C}$ bonds in the Prussian Blue structure are typically about $2,100 \mathrm{~cm}^{-1}$. The stretching frequency of $\mathrm{Mn}^{\mathrm{III}}-\mathrm{C}$ in freshly synthesized $\mathrm{Mn}^{\mathrm{II}}-\mathrm{N} \equiv \mathrm{C}-\mathrm{Mn}^{\mathrm{III}}$ was found to be $2,146 \mathrm{~cm}^{-1}$. After chemical reduction by $\mathrm{Na}_{2} \mathrm{~S}_{2} \mathrm{O}_{6}$, the stretching frequency of $\mathrm{Mn}^{\mathrm{II}}-\mathrm{C}$ in $\mathrm{Mn}^{\mathrm{II}}-\mathrm{N} \equiv \mathrm{C}-\mathrm{Mn}^{\mathrm{II}}$ was found to be $2,062 \mathrm{~cm}^{-1}$. Both of these values are in close agreement with those previously reported for a $\mathrm{C}$-coordinated manganese, thus supporting our hypothesis that the electrochemical activity near $0 \mathrm{~V}$ is due to the hexacyanomanganate groups ${ }^{39}$.

The X-ray photoelectron spectroscopy (XPS) (Supplementary Fig. S3) and transmission electron microscopy electron energy loss spectroscopy (TEM EELS) (Supplementary Fig. S5) spectra of the as-synthesized $\mathrm{Mn}^{\mathrm{II}}-\mathrm{N} \equiv \mathrm{C}-\mathrm{Mn}^{\mathrm{III}}$ and the chemically reduced $\mathrm{Mn}^{\mathrm{II}}-\mathrm{N} \equiv \mathrm{C}-\mathrm{Mn}^{\mathrm{II}}$ powders were also measured, but because of reasons described in the Supplementary Information it was not possible to ascribe the reduction to a specific manganese site.

On the basis of these FTIR and electrochemical data, we therefore conclude that the redox behaviour of manganese hexacyanomanganate proceeds by the following mechanisms:

The P-site manganese is electrochemically active around $0.7 \mathrm{~V}$ vs SHE (Equation 2).

$$
\mathrm{Mn}^{\mathrm{III}}\left[\mathrm{Mn}^{\mathrm{III}}(\mathrm{CN})_{6}\right]+\mathrm{A}^{+}+\mathrm{e}^{-}=\operatorname{AMn}^{\mathrm{II}}\left[\mathrm{Mn}^{\mathrm{III}}(\mathrm{CN})_{6}\right] \mathrm{E}^{0}=0.7 \mathrm{~V}
$$

The hexacyanomanganate group is then reduced near $0 \mathrm{~V}$ vs SHE (Equation 3).

$$
\mathrm{AMn}^{\mathrm{II}}\left[\mathrm{Mn}^{\mathrm{III}}(\mathrm{CN})_{6}\right]+\mathrm{A}^{+}+\mathrm{e}^{-}=\mathrm{A}_{2} \mathrm{Mn}^{\mathrm{II}}\left[\mathrm{Mn}^{\mathrm{II}}(\mathrm{CN})_{6}\right] \mathrm{E}^{0}=0.0 \mathrm{~V}
$$

In the first study to document the electrochemical activity of hexacyanomanganate-based Prussian Blue analogues, Scholz and Dostal proposed that the lowest reaction of these materials was due to the further reduction of hexacyanomanganate(II) to hexacyanomanganate(I). The exceedingly rare $\mathrm{Mn}(\mathrm{I})$ state is known to occur only in a few organometallic complexes, in the presence of very soft ligands like $\mathrm{CO}$ or $\mathrm{CN}$. In fact, $\mathrm{K}_{5} \mathrm{Mn}(\mathrm{CN})_{6}$ has been previously synthesized by chemical reduction of $\mathrm{K}_{4} \mathrm{Mn}(\mathrm{CN})_{6}$ using aluminum as a reducing agent ${ }^{43-45}$. The mechanism for this reaction is shown in Equation 4:

$$
\mathrm{A}_{2} \mathrm{Mn}^{\mathrm{II}}\left[\mathrm{Mn}^{\mathrm{II}}(\mathrm{CN})_{6}\right]+\mathrm{A}^{+}+\mathrm{e}^{-}=\mathrm{A}_{3} \mathrm{Mn}^{\mathrm{II}}\left[\mathrm{Mn}^{\mathrm{I}}(\mathrm{CN})_{6}\right] \mathrm{E}^{0}=-0.7 \mathrm{~V}
$$

In situ synchrotron X-ray diffraction (Fig. 4b,c and Supplementary Fig. S1) showed that during the reversible electrochemical processes (2) and (3), the material retains its face-centred cubic crystal structure and the lattice parameter decreases from $10.696 \AA$ for the as-synthesized $\mathrm{Mn}^{\mathrm{II}}-\mathrm{N} \equiv \mathrm{C}-$ $\mathrm{Mn}^{\mathrm{III}}$ to 10.653 and $10.530 \AA$ for $\mathrm{Mn}^{\mathrm{II}}-\mathrm{N} \equiv \mathrm{C}-\mathrm{Mn}^{\mathrm{II}}$ and $\mathrm{Mn}^{\mathrm{II}}-$ $\mathrm{N} \equiv \mathrm{C}-\mathrm{Mn}^{\mathrm{I}}$, respectively. We believe that this unusual behaviour corresponds to a decrease in the radius of $\left[\mathrm{Mn}^{\mathrm{III}}(\mathrm{CN})_{6}\right]^{3-}$ ions during their reduction to $\left[\mathrm{Mn}^{\mathrm{II}}(\mathrm{CN})_{6}\right]^{4-}$ and $\left[\mathrm{Mn}^{\mathrm{I}}(\mathrm{CN})_{6}\right]^{5-}$, as previously demonstrated in the case of hexacyanoferrates ${ }^{46}$.

Safety considerations. Further physical characterization of the $\mathrm{Cu}^{\mathrm{II}}-\mathrm{N} \equiv \mathrm{C}-\mathrm{Fe}^{\mathrm{III} / \mathrm{II}}$ cathode and the $\mathrm{Mn}^{\mathrm{II}}-\mathrm{N} \equiv \mathrm{C}-\mathrm{Mn}^{\mathrm{III} / \mathrm{II}}$ anode was performed with thermogravimetric analysis mass spectroscopy (TGA-MS). Both materials were found to lose about $25 \%$ water (Fig. 5). This accounts for the discrepancy between the 
a

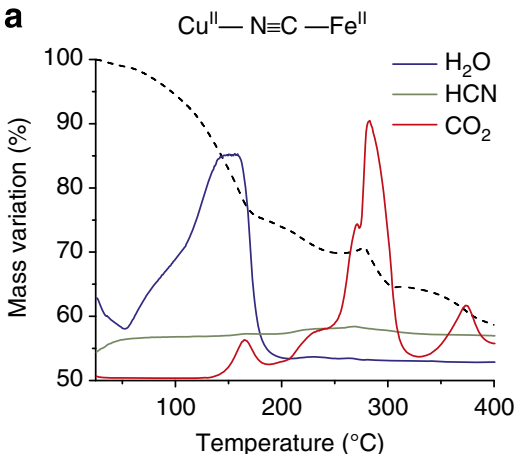

C

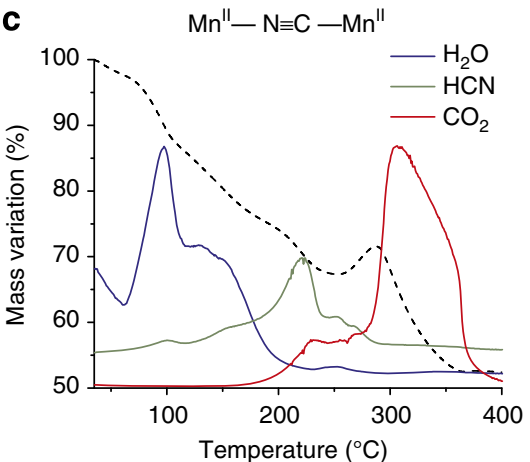

b

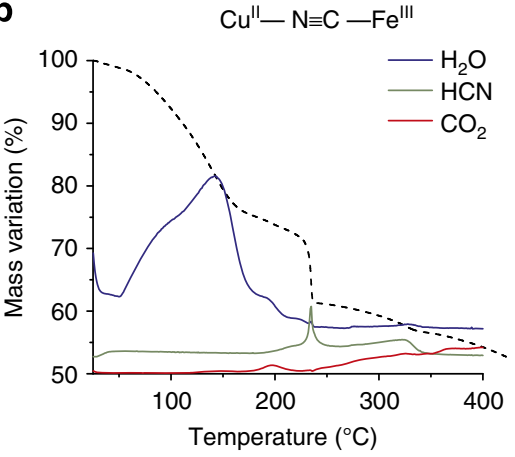

d

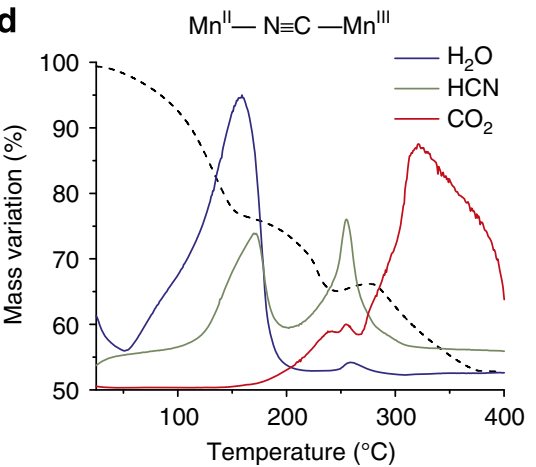

Figure 5 | Electrode materials thermal stability. Thermogravimetric analysis-mass spectrometry (TGA-MS) under inert $\left(\mathrm{N}_{2}\right)$ atmosphere of (a) reduced $\left(\mathrm{Cu}-\mathrm{N} \equiv \mathrm{C}-\mathrm{Fe}{ }^{\prime \prime}\right)$ and $(\mathbf{b})$ oxidized $\left(\mathrm{Cu}^{\prime \prime}-\mathrm{N} \equiv \mathrm{C}-\mathrm{Fe}^{\mathrm{III}}\right)$ copper hexacyanoferrate shows that these materials is about 25 wt\% of water and that $\mathrm{HCN}$ is not released from the structure for temperatures higher than $200^{\circ} \mathrm{C}$. Because of the lower stability of the $\mathrm{Mn}-\mathrm{C}$ bond, (c) reduced $\left(\mathrm{Mn} n^{\prime \prime}-\mathrm{N} \equiv \mathrm{C}-\mathrm{Mn}{ }^{\prime \prime}\right)$ and $(\mathbf{d})$ oxidized $\left(\mathrm{Mn}^{\mathrm{II}}-\mathrm{N} \equiv \mathrm{C}-\mathrm{Mn}^{\mathrm{III}}\right)$ manganese hexacyanomanganate release $\mathrm{HCN}$ starting from $120^{\circ} \mathrm{C}$, temperature high enough for a water-based electrolyte. As general trend, the lower is the oxidation state, the higher is the stability of the material being $\mathrm{CN}$ a soft base it forms a stronger bond with soft metals, therefore with a lower oxidation state.

observed specific capacities of Prussian Blue analogues in aqueous cells $\left(\sim 60 \mathrm{mAh}^{-1}\right)$ and the theoretical capacities calculated from the anhydrous chemical formulae $\left(\sim 80 \mathrm{mAhg}^{-1}\right)$. In addition, both materials were found to be quite stable against $\mathrm{HCN}$ release. The $\mathrm{Cu}^{\mathrm{II}}-\mathrm{N} \equiv \mathrm{C}-\mathrm{Fe}^{\mathrm{III}}$ cathode did not begin to release $\mathrm{HCN}$ until $200^{\circ} \mathrm{C}$, which is also the reported decomposition temperature for potassium ferricyanide. The $\mathrm{Mn}^{\mathrm{II}}$ $\mathrm{N} \equiv \mathrm{C}-\mathrm{Mn}^{\mathrm{III}}$ anode did not begin to release $\mathrm{HCN}$ until $120^{\circ} \mathrm{C}$, a temperature higher than that at which aqueous batteries fail due to electrolyte evaporation. When reduced, both $\mathrm{Cu}^{\mathrm{II}}-\mathrm{N} \equiv \mathrm{C}-\mathrm{Fe}^{\mathrm{II}}$ and $\mathrm{Mn}^{\mathrm{II}}-\mathrm{N} \equiv \mathrm{C}-\mathrm{Mn}^{\mathrm{II}}$ show improved thermal stability. These TGA-MS results can be interpreted in terms of the strength of the $\mathrm{N} \equiv \mathrm{C}-\mathrm{M}$ bond: the $\mathrm{N} \equiv \mathrm{C}-\mathrm{Fe}$ bond is much stronger than the $\mathrm{N} \equiv \mathrm{C}-\mathrm{Mn}$ bond, and therefore more stable ${ }^{45}$. At the same time, a soft ligand like $\mathrm{CN}$ forms stronger bonds with softer ions, hence it loses stability when bonded to high oxidation state cations. In summary, thermal stability analysis using TGA-MS showed that these materials are safe for use in practical batteries for many stationary and portable applications.

Dehydrated perchlorate salts do pose flammability hazards, but in aqueous solutions they are not hazardous. In particular, sodium perchlorate is highly hygroscopic, having one of the highest solubilities of any sodium salt in water. Replacement of perchlorate with an even more benign sodium salt will be a topic of future study.

\section{Discussion}

Full batteries containing a $\mathrm{Cu}^{\mathrm{II}}-\mathrm{N} \equiv \mathrm{C}-\mathrm{Fe}^{\mathrm{III} / \mathrm{II}}$ cathode, a $\mathrm{Mn}^{\mathrm{II}}-$ $\mathrm{N} \equiv \mathrm{C}-\mathrm{Mn}^{\mathrm{III} / \mathrm{II}}$ anode and excess $10 \mathrm{M} \mathrm{NaClO}_{4}$ electrolyte were characterized using galvanostatic cycling. In such cells, the cathode operates between 1.15 and $0.85 \mathrm{~V}$ vs SHE, while the anode operates between $-0.2 \mathrm{~V}$ and $0.2 \mathrm{~V}$ (Fig. 6a). This results in a full cell that operates between 1.35 and $0.65 \mathrm{~V}$, with an average discharge voltage of $0.95 \mathrm{~V}$. Although this cell voltage is lower than those of commercial lithium-ion and lead acid cells, it is comparable to the nominal voltages of vanadium redox flow batteries. Because of the high ionic conductivity of the electrolyte and rapid reaction of the electrodes, very little voltage hysteresis occurs during fast charge and discharge, and little of the nominal voltage of the cell is lost even at a 6 min (10C) cycling rate (Fig. 6b). The low voltage hysteresis observed during rapid cycling, along with a high coulombic efficiency of over $99.9 \%$, results in a very high round trip energy efficiency: $95.4 \%$ at a $10 \mathrm{C}$ rate and $84.2 \%$ even at a $50 \mathrm{C}$ rate (Fig. 6c). Finally, the very low full cell impedance (Fig. 6d) and low voltage hysteresis of this battery allow much of its low-rate capacity to be utilized at high rates. At a $10 \mathrm{C}$ rate, $92.9 \%$ of the maximum discharge capacity was retained above $0.65 \mathrm{~V}$, while at a $50 \mathrm{C}$ rate, $73.3 \%$ was still available.

Extended cycling of full batteries containing a $\mathrm{Cu}^{\mathrm{II}}-\mathrm{N} \equiv \mathrm{C}-$ $\mathrm{Fe}^{\mathrm{III} / \mathrm{II}}$ cathode and a $\mathrm{Mn}^{\mathrm{II}}-\mathrm{N} \equiv \mathrm{C}-\mathrm{Mn}^{\mathrm{III} / \mathrm{II}}$ anode was also performed. After 1,000 cycles at a $10 \mathrm{C}$ rate, there was no measurable capacity loss (Fig. 6d). The coulombic efficiency during extended cycling was $99.8 \%$.

In summary, this novel, symmetric open-framework electrode battery delivers a maximum specific energy of $27 \mathrm{Wh} \mathrm{kg}^{-1}$ at a $1 \mathrm{C}$ rate on a basis of the masses of the active materials. Furthermore, this battery has a specific energy of $15 \mathrm{Wh} \mathrm{kg}^{-1}$, a specific power of $693 \mathrm{~W} \mathrm{~kg}^{-1}$ and an $84.2 \%$ energy efficiency when cycled at a $50 \mathrm{C}$ rate. These properties, together with the outstanding cycle life and low active materials cost, make this 
a

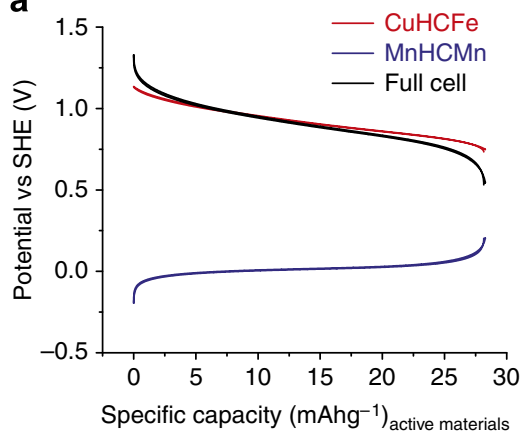

b

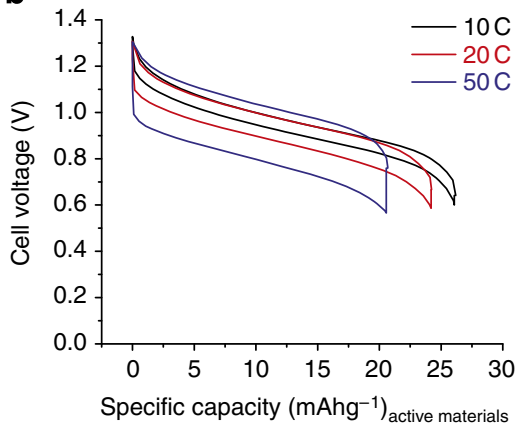

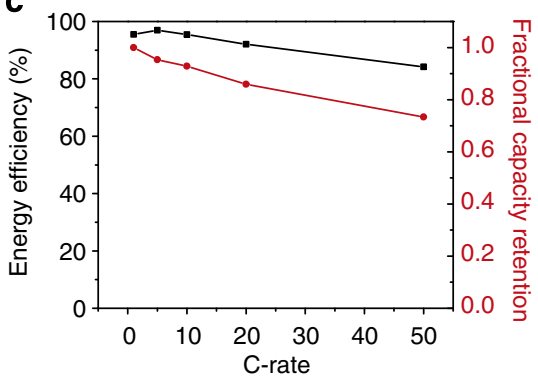

d

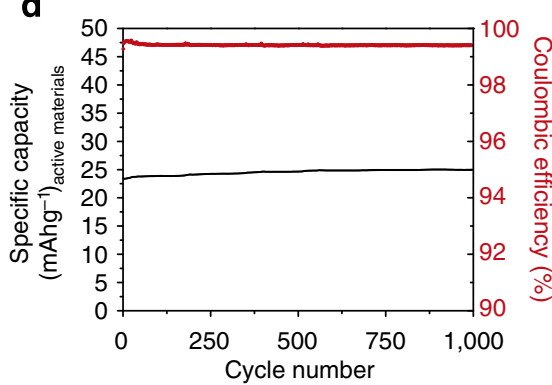

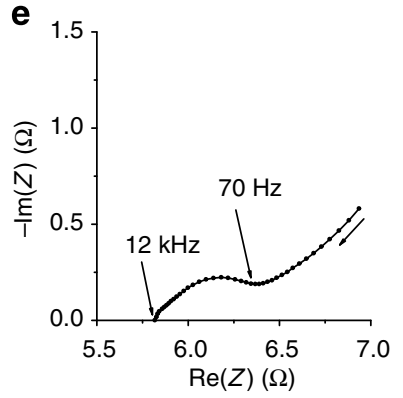

Figure 6 | Full cell electrochemical characterization. (a) Potential profiles of the copper hexacyanoferrate $\left(\mathrm{Cu}{ }^{\text {II }}-\mathrm{N} \equiv \mathrm{C}-\mathrm{Fe}^{\text {III/II }}\right)$ positive electrode, the manganese hexacyanomanganate $\left(\mathrm{Mn}^{\|}-\mathrm{N} \equiv \mathrm{C}-\mathrm{Mn}^{\mathrm{III} / \mathrm{II}}\right)$ negative electrode and the full cell voltage at a $1 \mathrm{C}$ rate. (b) The full cell voltage profiles at different $\mathrm{C}$ rates $\left(10 \mathrm{C}, 20 \mathrm{C}, 50 \mathrm{C}\right.$ ). (c) Energy efficiency and fractional capacity retention as a function of $\mathrm{C}$ rate. (d) $\mathrm{Cycling}$ of the $\mathrm{Cu} \mathrm{Cl}^{\mathrm{II}} \mathrm{N} \equiv \mathrm{C}-\mathrm{Fe} \mathrm{III}^{\mathrm{II}}$ $\mathrm{Mn}^{\mathrm{II}}-\mathrm{N} \equiv \mathrm{C}-\mathrm{Mn}^{\mathrm{III} / \mathrm{Il}}$ cell at a rate of $10 \mathrm{C}$ showed no capacity loss after 1,000 cycles and a coulombic efficiency of $99.8 \%$. (e) The specific energy vs specific power plot shows intermediate performance between lithium ion batteries and ultracapacitors, ideally positioning this technology for short-term grid-scale energy storage, especially to handle transients.

battery attractive for grid-related applications, including the smoothing of intermittent variations in power production associated with the integration of renewable energy on the grid.

\section{Methods}

Copper hexacyanoferrate synthesis. Preparation of nanoparticulate copper hexacyanoferrate was based on our recently reported synthesis procedures ${ }^{7}$. In brief, equal volumes of $40 \mathrm{mM} \mathrm{Cu}\left(\mathrm{NO}_{3}\right)_{2}$ (Alfa Aesar) and $20 \mathrm{mM} \mathrm{K}_{3} \mathrm{Fe}(\mathrm{CN})_{6}$ (Sigma Aldrich) were combined by simultaneous, dropwise addition into water under vigorous stirring. An excess of $\mathrm{Cu}^{+2}$ is necessary for precipitation and particle growth. All of the $\mathrm{Fe}(\mathrm{CN})_{6}$ is oxidized initially, but fully charged $\mathrm{Cu}^{\mathrm{II}}-\mathrm{N} \equiv \mathrm{C}-\mathrm{Fe}^{\mathrm{III}}$ has a potential high enough to oxidize water. Thus, spontaneous partial reduction of $\mathrm{Cu}^{\mathrm{II}}-\mathrm{N} \equiv \mathrm{C}-\mathrm{Fe}^{\mathrm{III}}$ occurs, resulting in a fractional initial charge state, typically about $80 \%$. Five minutes after complete addition of the $\mathrm{Cu}^{\mathrm{II}}-\mathrm{N} \equiv \mathrm{C}-\mathrm{Fe}^{\mathrm{III}}$ precursors, $0.1 \mathrm{M} \mathrm{Na}_{2} \mathrm{~S}_{2} \mathrm{O}_{3}$ was added until a desired molar ratio of $\mathrm{Fe}^{\mathrm{III}}(\mathrm{CN})_{6}^{-3}$ to $\mathrm{S}_{2} \mathrm{O}_{3}^{-2}$ was reached. The colour of $\mathrm{Cu}^{\mathrm{II}}-\mathrm{N} \equiv \mathrm{C}-\mathrm{Fe}^{\mathrm{II}}$ changed from tan to purple upon addition of $\mathrm{Na}_{2} \mathrm{~S}_{2} \mathrm{O}_{3}$, indicating a successful reduction. The CuHCF was filtered, washed with water and dried in vacuum at room temperature.

Manganese hexacyanomanganate synthesis. A similar preparation method was used for manganese (II) hexacyanomanganate (III). $0.5 \mathrm{~g}(15 \mathrm{mmol})$ of solid $\mathrm{K}_{3} \mathrm{Mn}(\mathrm{CN})_{6}$ was added to a $50 \mathrm{ml}$ solution of $0.1 \mathrm{M} \mathrm{Mn}\left(\mathrm{NO}_{3}\right)_{2}(50 \mathrm{mmol})$ using ultrapure distilled water, in a dark container, under vigorous stirring for $20 \mathrm{~min}$. The resulting light brown precipitate was washed and centrifuged three times with $25 \mathrm{ml}$ of water and then two more times with $25 \mathrm{ml}$ of acetonitrile before being dried under vacuum at room temperature. The chemically-reduced manganese(II) hexacyanomanganate(II) was obtained by reduction of $\mathrm{Mn}^{\mathrm{II}}-\mathrm{N} \equiv \mathrm{C}-\mathrm{Mn}^{\text {III }}$ with a $0.1 \mathrm{M}$ solution of sodium tetrathionate.

Chromium hexacyanomanganate synthesis. To synthesize chromium (II) hexacyanomanganate (III), $0.5 \mathrm{~g}$ of $\mathrm{CrCl}_{2}$ was dissolved in $35 \mathrm{ml} \mathrm{H}_{2} \mathrm{O} .0 .5 \mathrm{~g}$ $\mathrm{K}_{3} \mathrm{Mn}(\mathrm{CN})_{6}$ dissolved in $20 \mathrm{ml}$ of $10 \mathrm{mM} \mathrm{KCN}$ solution and then added to the $\mathrm{CrCl}_{2}$ solution and stirred for $3 \mathrm{~h}$ in a dark container. The excess $\mathrm{CN}^{-}$from the $\mathrm{KCN}$ helped to slow hydrolysis of the $\mathrm{Cr}^{2+}$. The resulting dark brown powder was centrifuged and washed three times in water, followed by a final wash in methanol, before being dried in vacuum at room temperature.
Electrodes preparation. Slurries containing $\mathrm{Cu}^{\mathrm{II}}-\mathrm{N} \equiv \mathrm{C}-\mathrm{Fe}^{\mathrm{II}}$ or $\mathrm{Mn}^{\mathrm{II}}-\mathrm{N} \equiv \mathrm{C}-$ $\mathrm{Mn}^{\mathrm{III}}$ amorphous carbon (Super P Li), poly(vinylidene) difluoride (PVDF, Kynar HSV900) and graphite (Timcal KS6) in a ratio of 80:9:9:2 were prepared by grinding these materials by hand and then dispersing them in 1-methyl-2-pyrolidinone (NMP). Electrodes with mass loadings of about $10 \mathrm{mg} \mathrm{cm}^{-2}$ were prepared by spreading the slurry on a carbon cloth current collector (Fuel Cell Earth/ Ballard Avcarb). The electrodes were dried in vacuum at $60^{\circ} \mathrm{C}$ for $1 \mathrm{~h}$.

Electrochemical cell setup. Flooded full cells containing a CuHCF cathode, an $\mathrm{MnHCMn}$ anode, $10 \mathrm{M}$ sodium perchlorate electrolyte saturated with $\mathrm{Mn}\left(\mathrm{ClO}_{4}\right)_{2}$ at $\mathrm{pH}=6.4$ and a $\mathrm{Ag} / \mathrm{AgCl} 3.5 \mathrm{M}$ reference electrode were prepared in a nitrogenfilled glove box. The presence of $\mathrm{Mn}\left(\mathrm{ClO}_{4}\right)_{2}$ in solution further decrease the solubility of MnHCMn in the electrolyte, thus resulting in improved cycle life performance. Moreover, the addition of $\mathrm{Mn}\left(\mathrm{ClO}_{4}\right)_{2}$ in the solution results in the precipitation of $\mathrm{Mn}(\mathrm{OH})_{2}$ that buffer the $\mathrm{pH}$ at 6.4. The MnHCMn electrode is sensitive to oxidation, hence the cell must be kept oxygen-free to achieve efficient anode cycling at potentials below the SHE.

\section{References}

1. Yang, Z. et al. Electrochemical Energy Storage for Green Grid. Chem. Rev. 111, 3577-3613 (2011).

2. Rastler, D. Electricity energy storage technology options: a white paper primer on applications, costs and benefits (2010).

3. Rastler, D. \& Kamath, H. Energy storage: Enabling grid-ready solutions EPRI J 20-23 (2010).

4. University of California, B. S. of L., University of California, L. A. \& University of California, S. D. 2020 STRATEGIC ANALYSIS OF ENERGY STORAGE IN CALIFORNIA (2011).

5. Rastler, D. Electricity Energy Storage Technology Options. EPRI Rep. 170 (2010).

6. Barnhart, C. J. \& Benson, S. M. On the importance of reducing the energetic and material demands of electrical energy storage. Energy Environ. Sci. 6, 1083 (2013).

7. Barnhart, C. J., Dale, M., Brandt, A. R. \& Benson, S. M. The energetic implications of curtailing versus storing solar- and wind-generated electricity. Energy Environ. Sci. 6, 2804 (2013). 
8. Wessells, C. D., Peddada, S. V., McDowell, M. T., Huggins, R. a. \& Cui, Y. The Effect of Insertion Species on Nanostructured Open Framework Hexacyanoferrate Battery Electrodes. J. Electrochem. Soc. 159, A98 (2012).

9. Wessells, C. D. et al. Tunable reaction potentials in open framework nanoparticle battery electrodes for grid-scale energy storage. ACS Nano 6, 1688-1694 (2012).

10. Wessells, C. D., Huggins, R. A. \& Cui, Y. Copper hexacyanoferrate battery electrodes with long cycle life and high power. Nat. Commun. 2, 550 (2011).

11. Wessells, C. D., Peddada, S. V., Huggins, R. A. \& Cui, Y. Nickel hexacyanoferrate nanoparticle electrodes for aqueous sodium and potassium ion batteries. Nano Lett. 11, 5421-5425 (2011).

12. Neff, V. D. Some Performance Characteristics of a Prussian Blue Battery. J. Electrochem. Soc. 132, 1382 (1985).

13. Neff, V. D. Electrochemical Oxidation and Reduction of Thin Films of Prussian Blue. J. Electrochem. Soc. 125, 886-887 (1978).

14. Messina, R., Perichon, J. \& Broussely, M. Mécanismes de la réduction électrochimique en milieu non aqueux de materiaux cathodiques utilisés dans les piles au lithium. IV. Réduction d'électrodes membranaires d'hexacyanoferrates (II et III) d'argent dans le mélange carbonate de propylène1,2-diméth. J. Appl. Electrochem. 9, 677-684 (1979).

15. Messina, R. \& Perichon, J. Mécanisme de la réduction électrochimique en milieu non aqueux de materiaux cathodiques utilises dans les piles au lithium. V. Utilisation des hexacyanoferrates de fer (II et III) comme materiaux cathodiques reversibles. J. Appl. Electrochem. 10, 655-663 (1980).

16. Honda, K. \& Hayashi, H. Prussian Blue containing nafion composite film as rechargeable battery. J. Electrochem. Soc. 285, 1330-1334 (1987).

17. Grabner, E. W. \& Kalwellis-Mohn, S. Hexacyanoferrate layers as electrodes for secondary cells. J. Appl. Electrochem. 17, 653-656 (1987).

18. Kaneko, M. \& Okada, T. A secondary battery composed of multilayer Prussian Blue and its reaction characteristics. J. Electroanal. Chem. Interfacial Electrochem. 255, 45-52 (1988).

19. Kalwellis-Mohn, S. \& Grabner, E. W. A secondary cell based on thin layers of zeolite-like nickel hexacyanometallates. Electrochim. Acta 34, 1265-1269 (1989).

20. Jayalakshmi, M. \& Scholz, F. Performance characteristics of zinc hexacyanoferrate/Prussian blue and copper hexacyanoferrate/Prussian blue solid state secondary cells. J. Power Sources 91, 217-223 (2000).

21. Tung, T.-S., Chen, L.-C. \& Ho, K.-C. An indium hexacyanoferrate-tungsten oxide electrochromic battery with a hybrid $\mathrm{K}^{+} / \mathrm{H}^{+}$-conducting polymer electrolyte. Solid State Ionics 165, 257-267 (2003).

22. Eftekhari, A. A high-voltage solid-state secondary cell based on chromium hexacyanometallates. J. Power Sources 117, 249-254 (2003).

23. Eftekhari, A. Fabrication of all-solid-state thin-film secondary cells using hexacyanometallate-based electrode materials. J. Power Sources 132, 291-295 (2004).

24. Okubo, M. et al. Switching Redox-Active Sites by Valence Tautomerism in Prussian Blue Analogues $\mathrm{A}_{\mathrm{x}} \mathrm{Mn}_{\mathrm{y}}\left[\mathrm{Fe}(\mathrm{CN})_{6}\right] \cdot \mathrm{nH}_{2} \mathrm{O}(\mathrm{A}: \mathrm{K}, \mathrm{Rb})$ : Robust Frameworks for Reversible Li Storage. J. Phys. Chem. Lett. 1, 2063-2071 (2010).

25. Ludi, A. \& Güdel, H. Structural chemistry of polynuclear transition metal cyanides. Inorg. Chem. 14, 1-21 (1973).

26. Herren, F., Fischer, P., Ludi, A., Hälg, W. \& Haelg, W. Neutron diffraction study of Prussian Blue, $\mathrm{Fe}_{4}\left[\mathrm{Fe}(\mathrm{CN})_{6}\right]_{3} \cdot \mathrm{xH}_{2} \mathrm{O}$. Location of water molecules and long-range magnetic order. Inorg. Chem. 19, 956-959 (1980).

27. Buser, H. J., Schwarzenbach, D., Petter, W. \& Ludi, A. The crystal structure of Prussian Blue: $\mathrm{Fe}_{4}\left[\mathrm{Fe}(\mathrm{CN})_{6}\right]_{3} \cdot \mathrm{xH}_{2} \mathrm{O}$. Inorg. Chem. 16, 2704-2710 (1977).

28. Pasta, M., Wessells, C. D., Huggins, R. A. \& Cui, Y. A high-rate and long cycle life aqueous electrolyte battery for grid-scale energy storage. Nat. Commun. 3, 1149 (2012).

29. Yang, Y. et al. Quantitative measurement of cyanide released from Prussian Blue*. Clin. Toxicol. 45, 776-781 (2007).

30. Stilwell, D. E., Park, K. H. \& Miles, M. H. Electrochemical studies of the factors influencing the cycle stability of Prussian Blue films. J. Appl. Electrochem. 22, 325-331 (1992).

31. Li, W., Dahn, J. R. \& Wainwright, D. S. Rechargeable lithium batteries with aqueous electrolytes. Science 264, 1115-1118 (1994).

32. Wang, G. X., Zhong, S., Bradhurst, D. H., Dou, S. X. \& Liu, H. K. Secondary aqueous lithium-ion batteries with spinel anodes and cathodes. J. Power Sources 74, 198-201 (1998)

33. Wang, G. et al. An Aqueous Rechargeable Lithium Battery with Good Cycling Performance. Angew. Chemie 119, 299-301 (2007).
34. Luo, J. Y. \& Xia, Y. Y. Aqueous Lithium-ion Battery $\operatorname{LiTi}_{2}\left(\mathrm{PO}_{4}\right)_{3} / \mathrm{LiMn}_{2} \mathrm{O}_{4}$ with High Power and Energy Densities as well as Superior Cycling Stability. Adv. Funct. Mater. 17, 3877-3884 (2007).

35. Granqvist, C. G. Handbook of Inorganic Electrochromic Materials (Elsevier Science, 1995).

36. Scholz, F. \& Dostal, A. The Formal Potentials of Solid Metal Hexacyanometalates. Angew. Chemie Int. Ed. 34, 2685-2687 (1996).

37. Dostal, A. Festkörperreaktionen an metallhexacyanometallat-modifiziertem Elektroden. Dr. Diss. Math. Fak. I der Humboldt-Universität zu Berlin (1998).

38. Reguera, E., Bertrán, J. A. \& Nuñez, L. Study of the linkage isomerization process in hexacyanometallates. Polyhedron 13, 1619-1624 (1994).

39. Brown, D. B. \& Shriver, D. F. Structures and solid-state reactions of Prussian blue analogs containing chromium, manganese, iron, and cobalt. Inorg. Chem. 8, 37-42 (1969).

40. Shaojun, D. \& Fengbin, L. Researches on chemically modified electrodes: Part XV. Preparation and electrochromism of the vanadium hexacyanoferrate film modified electrode. J. Electroanal. Chem. Interfacial Electrochem. 210, 31-44 (1986).

41. Jiang, M., Zhou, X. \& Zhao, Z. Preparation and characterization of mixedvalent titanium hexacyanoferrate film modified glassy carbon electrode. J. Electroanal. Chem. Interfacial Electrochem. 292, 289-296 (1990).

42. Asakura, D. et al. Fabrication of a Cyanide-Bridged Coordination Polymer Electrode for Enhanced Electrochemical Ion Storage Ability. J. Phys. Chem. C 116, 8364-8369 (2012).

43. Manchot, W. \& Gall, H. Über einwertiges Mangan. Berichte der Dtsch. Chem. Gesellschaft (A B Ser.) 60, 191-194 (1927).

44. Schwochau, K. \& Herr, W. Beiträge zur Komplexchemie des Technetiums. II. Darstellung und Eigenschaften von Kalium-cyanotechnetat(I). Zeitschrift für Anorg. und Allg. Chemie 319, 148-158 (1962).

45. Griffith, W. P. Cyanide complexes of the early transition metals (groups IVa-VIIa). Coord. Chem. Rev. 17, 177-247 (1975).

46. Dostal, A., Kauschka, G., Reddy, S. J. J. \& Scholz, F. Lattice contractions and expansions accompanying the electrochemical conversions of Prussian blue and the reversible and irreversible insertion of rubidium and thallium ions. J. Electroanal. Chem. 406, 155-163 (1996).

47. Bagkar, N. et al. Crystalline thin films of transition metal hexacyanochromates grown under Langmuir monolayer. Thin Solid Films 513, 325-330 (2006).

\section{Acknowledgements}

We acknowledge support from the Global Climate and Energy Project (GCEP) at Stanford as well as the US. Department of Energy (DOE), Office of Electricity Delivery \& Energy Reliability for this research through collaboration with the Pacific Northwest National Laboratory. Pacific Northwest National Laboratory is a multiprogram national laboratory operated for DOE by Battelle under Contract DEA C05-76RL01830. Portions of this research were carried out at the Stanford Synchrotron Radiation Lightsource, a national user facility operated by Stanford University on behalf of the U.S. Department of Energy, Office of Basic Energy Sciences. M.T.M. acknowledges support from the Chevron Stanford Graduate Fellowship and the National Science Foundation Graduate Fellowship. M.P. acknowledges the support of the Oronzio and Niccolò De Nora Foundation.

\section{Author contributions}

M.P. and Y.C. conceived the concept. M.P., C.D.W., R.A.H. and Y.C. designed electrochemical and physical measurements. M.P. and C.D.W. performed and analyzed electrochemical measurements and physical characterization. M.P., J.N. and M.F.T designed and performed the in situ synchrotron X-ray diffraction measurements. M.P., C.D.W., R.A.H. and Y.C. co-wrote this paper. All the authors made comments to this paper.

\section{Additional information}

Supplementary Information accompanies this paper at http://www.nature.com/ naturecommunications

Competing financial interests: The authors declare no competing financial interests.

Reprints and permission information is available online at http://npg.nature.com/ reprintsandpermissions/

How to cite this article: Pasta, M. et al. Full open-framework batteries for stationary energy storage. Nat. Commun. 5:3007 doi: 10.1038/ncomms4007 (2014). 